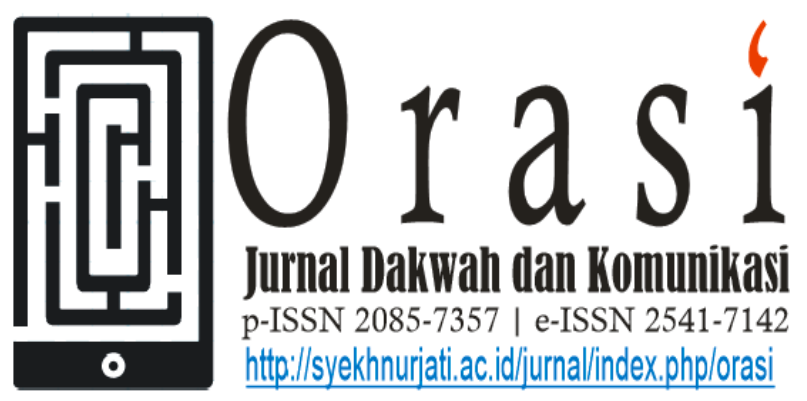

Volume 9 No. 2, PP 115 - 128; November 2018

\title{
PROGRAM PARTICIPATORY ACTION RESEARCH MELALUI PENDEKATAN DAKWAH BIL HAL
}

\author{
Mohamad Ghazali 1(*), Arif Abdul Haqq ${ }^{2}$ \\ Dosen IAIN Syekh Nurjati Cirebon \\ ghozali.iaincrb@gmail.com $^{(*)}$, mr.haqq@gmail.com
}

\begin{abstract}
ABSTRAK
Penlitian ini bertujuan untukn memberi gambaran secara menyeluruh tentang implementasi pendekatan dakwah bil hal dalam program participatory action research (PAR). Mendeskripsikan permasalahan yang terjadi di masyarakat dan penanggulangannya melalui program program participatory action research. Jenis Penelitian adalah Kualitatif deskriptif dengan pengumpulan data melalaui wawancara, observasi dan dokumentasi, analisis penelitian menggunakan analisis kualitatif deskriptif. Hasil penelitian menunjukkan bahwa pelaksanaan Dakwah PAR berbasis masjid dilaksanakan sejak tahun 2018 di Desa Kramatsampang Kecamatan Kersana Kabupaten Brebes dengan mengoptimalkan program PAR sebagai tempat sentra kegiatan, faktor pendukung dakwah bil hal dalam program PAR adalah adanya dukungan dari pemerintah, tokoh masyarakata, tokoh agama, dan tokoh pemuda termasuk majlis taklim. Adapun tantangan yang dihadapi adalah masih kurangnya sosialisasi dan pemahaman elemen-elemen masrarakat desa Kramatsampang terhadap strategi Dakwah bil hal program PAR. Untuk maksimalkan program PAR dengan pendekatan dakwah bil hal, maka dirumuskan berbagai kegaiatan yang mendukung program PAR dengan pendekatan dakwah Bil seperti pemetaan SWOT, Rural Rapid Assessment, Logical Framework Assessment.
\end{abstract}

Kata kunci: bil hal, dakwah, PAR, program, masyarakat

\section{PENDAHULUAN}

Strategi Dakwah bil hal adalah strategi mentransfer seruan nilai-nilai agama melalui tindakan suri tauladan yang nyata. Menurut Zakiyyah dan Haqq hal ini dimaksudkan agar si penerima dakwah (al-mad'ūlah) mengikuti jejak dan hal ikhwal si da'i 
(juru dakwah). Menurut Kurniawan (Bil

Hal Penciptaan Budaya Agama melalui Pembiasaan Shalat Berjamaah di Sekolah Menengah Pertama Islam AlAzhar 5 Kota Cirebon, 2017) dakwah bil hal (ajakan keagamaan dengan pemberian contoh perbuatan) perlu dilakukan tidak hanya sekedar transfer of knowledge tetapi juga untuk menanamkan nilai-nilai (transfer of values). Strategi dakwah jenis ini sangatlah efektif dan efisien bagi penerima dakwah. Al-Mawar (AlDakwah; Qawā'idwa Ushūl Mesir: , 1992, hal. 18) mengemukakan bahwa diakwah bi al-hāl, yaitu dakwah yang dilakukan dengan berbagai perbuatan dan kegiatan yang langsung menyentuh kepada masyarakat sebagai objek dakwah dengan karya.

Program participatory action research (PAR) melalui pendekatan dakwah bil hal senantiasa disertai dengan upaya-upaya ajakan nilai-nilai yang positif, terutama nilai-nilai religius. Kegiatan tersebut menurut Amin (2012) di antaranya bersilaturrahmi dengan masyarakat yang membutuhkan, turut serta dalam melaksanakan pengabdian kepada masyarakat, ringkasnya adalah strategi dakwah ini dilaksanakan sesuai kebutuhan masyarakat dengan ramburambu dalam menjalani kehidupan.
Konsepsi riil Islam tentang agenda dakwah sebenarnya telah ada dan masih banyak namun belum menjadi fokus untuk dikaji dan dikembangkan secara sistematis sehingga bisa dilakukan oleh banyak pihak (Hidayat, 2013). Lebih lanjut ia menuturkan optimalisasi dana wakaf, zakat, hibah yang dibuatkan sistem dan prinsip-prinsip kerja yang baik serta pengaturannya secara luas sehingga menjadi agenda bersama umat Islam untuk mengembangkannya.

Salah satu wujud nyata pengabdian kepada masyarakat adalah pelaksanaan program PAR berbasis mesjid yang jelas merupakan bagian dari dakwah bil hal. Dalam praktiknya, mahasiswa diharapkan mampu mengaplikasikan ilmu pengetahuan yang bersifat teori ke dalam lingkungan nyata sehingga diharapkan adanya kerjasama antara perguruan tinggi dan masyarakat. Dalam rangka meningkatkan percepatan pembangunan serta mewujudkan sinergitas dan harmonisasi pembangunan melalui peningkatan peran lembaga pendidikan secara terintegrasi maka diselenggarakan pengabdian kepada masyarakat berupa program. Jika dilihat dari kerusakan pada lingkungan ada dua jenis bencana akibat rusaknya daya dukung lingkungan. Pertama, kerusakan karena faktor internal, yakni kerusakan yang berasal alam sendiri. Bagi masyarakat, kerusakan ini sukar dihindari sebab merupakan bagian 
dari proses alam. Tidak sedikit kejadianya dalam waktu singkat, tetapi dampak atau akibat kejadianya dalam waktu lama. Oleh karena itu, yang bisa dilakukan adalah menyiagakan diri atau mempersiapkan manajemen bencana guna menimalkan banyaknya korban. Kedua, kerusakan kerena faktor eksternal, yaitu kerusakan lingkungan yang berasal dari perilaku manusia.Terutama beralasan demi meningkatkan kualitas dan kenyamanan hidup. Kerusakan daya dukung sebagai akibat dari kegiatankegiatan, seperti: industialisasi, penggunaan bahan bakar fosil dan limbah rumah tangga yang dibuang di sungaisungai (Sunu,2001:31).

\section{Kesadaran} masyarakat kramatsampang akan lingkungan masih sangat rendah. Hal ini dibuktikan dengan masih banyak warga yang membuang sampah rumah tangga di sungai sehingga sungai menjadi kotor dan tercemar. Di karenakan di desa kramatsamapang belum tersedia tempat pembuangan akhir (TPA) dan belum bisa mengelola sampah dengan baik Pemerintah desa kramatsampang baru merencanakan adanya TPA namun belum bisa terealisasikan.

Anton (2015) mengatakan bahwa kegiatan sosial kemasyarakatan yang direncanakan dari masjid telah menyadarkan masyarakat bahwa agama yang dianutnya terdapat hikmah-hikmah (wisdom) ketuhanan dan kemanusiaan yang mirip, atau bahkan sama antara satu sama lain, maka kearifan terdalam pada masing-masing tidak hanya dapat memerkaya dan mempersubur satu sama lain, tetapi juga dapat dan akan terus memberi kehangatan makna bagi mereka dan bahkan bagi masa depan anakanaknya.

Dalam upaya untuk mempengaruhi ataupun mengajak anggota masyarakat untuk menuju ke arah perubahan dibutuhkan upaya yang dilakukan secara berulang-ulang dan tentu saja ini akan membutuhkan waktu yang cukup lama (Sukmawati, 2013). Mahasiswa merupakan salah satu bagian dari kalangan elit di masyarakat yang terdidik dan terampil, serta sebagai agen perubahan pada masyarakat seharusnya mempunyai pemikiran yang lebih maju dan cerah untuk bisa menciptakan Sumber Daya Masyarakat (SDM) yang kreatif dan inovatif yang sebagai salah satu penunjang utama kemajuan suatu bangsa. Tumbuhnya sikap kreatif dan inovatif inilah masyarakat mampu mengembangkan segala sesuatu yang mereka miliki menjadi hal yang bernilai dan diperuntukkan demi kemakmuran hidup mereka.

Mahasiswa memiliki peranan penting di areal kampus maupun di lingkungan masyarakat sekitarnya untuk 
berperan aktif melaksanakan strategi dakwah bil hal. Mahasiswa diharapkan mampu menyumbangkan pengetahuannya kepada masyarakat di lingkungan sekitarnya. Sebab masyarakat itu sendiri telah berparadigma bahwa mahasiswa adalah row models masyarakat di masa depan yang memiliki nilai kependidikan yang lebih dan berpengetahuan luas. Sehingga apabila mahasiswa dan masyarakat bisa saling bertoleransi dan saling bekerja sama, maka akan terbentuk kehidupan masyarakat yang lebih terjamin mutu pengetahuannya dan dapat bersamasama tumbuh dan berkembang dalam harmoni.

Berdasar pada uraian latar belakang yang telah dikemukakan, maka sebagai masalah pokok dalam tulisan ini adalah bagaimana konsep dakwah melalui program PAR melalui pendekatan dakwah bil hal, dan sebagai sub masalah yang akan dibahas adalah: bagaimana konsep dakwah bil hal dalam kaitannya dengan program PAR, bagaimana implementasi dakwah melalui Program PAR melalui pendekatan dakwah bil hal.

\section{METODE PENELITIAN}

Pendekatan yang digunakan dalam penelitian ini adalah pendekatan kualitatif deskriptif. Usaha untuk melakukan penelusuran, pemahaman, penjelasan gejala dan kaitan hubungan antara gejala yang diteliti dari komponen tertentu menjadi dasar digunakannya pendekatan tersebut. Model yang digunakan untuk melakukan analisis data adalah Model Analisis Interaktif Miles dan Huberman. Menurut Sukmawati (2013) model tersebut dapat memiliki empat tahapan, yaitu: (1) Tahap pengumpulan data, pada tahap ini peneliti melakukan proses pengumpulan data dengan menggunakan teknik pengumpulan data yang telah ditentukan; (2) Tahap reduksi data, pada tahap ini, peneliti melakukan pemilihan, pemusatan perhatian pada penyederhanaan, pengabstrakan, dan transformasi data kasar yang muncul dari catatan-catatan tertulis dari lapangan; (3) Tahap penyajian data, tahap ini merupakan penyajian data dari informasi yang tersusun yang memberi kemungkinan adanya penarikan kesimpulan dan pengambilan tindakan; dan yang terakhir adalah (4) Tahap verifikasi/penarikan kesimpulan, pada tahap ini merupakan tahap akhir, yang berupa penarikan kesimpulan dari data yang telah ditampilkan. Adapun ilustrasinya ditampilkan pada Gambar 1 berikut. 


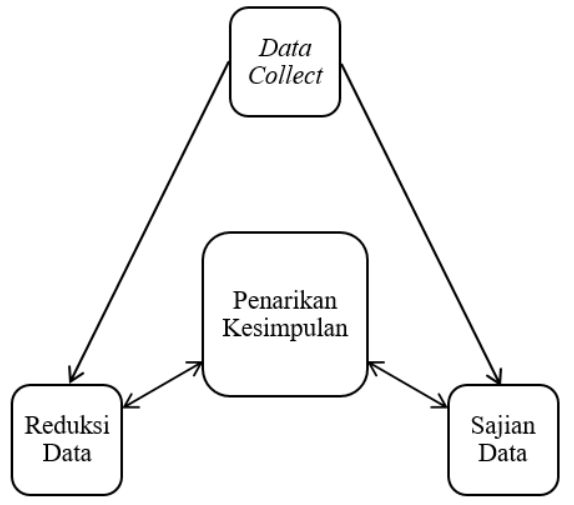

Gambar 1. Model Analisis Interaktif dari Miles dan Huberman

Teknik pengumpulan data menggunakan metode: (1) pengamatan, yang digunakan untuk mengamati hasil berupa kondisi fisik apa saja yang telah dilaksanakan/diwujudkan oleh kepala desa dalam rangka pembaharuan kepada masyarakat tentang pertanian berbasis teknologi dan pendukungnya. Kegiatan masyarakat dalam mempraktekkan pertanian berbasis teknologi. Kegiatan lainnya yang mendukung pelaksanaan pembaharuan pada masyarakat Desa Mlatiharjo; (2) wawancara, yang dugnakan untuk mewawancarai kepala desa sebagai agen perubahan utama, perangkat desa, dan penduduk Desa Sumurkondang, (3) dokumentasi, dokumen digunakan sebagai sumber sekunder, dalam hal ini berarti dokumen bias digunakan sebagai suatu cara untuk melakukan pengecekan silang (cross check) terhadap informasi yang telah diperoleh dari sumber lain, missal dari hasil wawancara; (4) triangulasi, yaitu teknik yang menggabungkan beberapa teknik pengumpulan data dan sumber data yang telah ada. Uji objektivitas data penelitian ini dilakukan dengan menggunakan teknik: (1) triangulasi sumber, yaitu dengan melakukan pengecekan data tentang kondisi masyarakat dari sumber lisan (informan) seperti kepala desa, perangkat desa dan sumber pendukung lainnya dengan sumber tertulis (misal data monografi desa); (2) review informan, yaitu dengan melakukan pengecekan hasil penelitian oleh para informan.

\section{HASIL DAN PEMBAHASAN}

Program PAR melalui pendekatan dakwah bil hal merupakan salah satu jenis pengabdian kepada masyarakat bertujuan membentuk, membina, dan mengembangkan PAR sebagai terobosan baru dalam pemberdayaan masyarakat, melalui pemanfaatan potensi SDM dan SDA lokal. Adapun tujuan kegiatan yang dilaksanakan adalah sebagai berikut:

1. Meningkatkan kepedulian dan kemampuan mahasiswa mempelajari dan mengatasi permasalahan keluarga dan penduduk melalui bantuan penyusunan rencana dan pendampingan pada pelaksanaan program yang inovatif dan kreatif melalui penerapan ilmu dan teknologi 
bersama masyarakat dan lembaga pedesaan lainya.

2. Meningkatkan kemampuan mahasiswa melaksanakan kegiatan pengembangan masyarakat sesuai arahan pembangunan manusia (human development), mencapai target dan sasaran Millennium Development Goals (MDGs), kompetensi, potensi, sumberdaya dan kemampuan lingkungan dalam wadah kerjasama masyarakat, pemerintah, swasta dan lembaga lainnya.

3. Menggalang komitmen, kepedulian dan kerjasama berbagai stakeholders (Pemda, swasta, LSM dan masyarakat) dalam mengatasi permasalahan dan ketidakberdayaan penduduk dan keluarga lainnya untuk mewujudkan keluarga sejahtera mandiri.

4. Membantu dalam mempersiapkan keluarga dan masyarakat agar memiliki kemampuan untuk memanfaatkan setiap fasilitas dan dukungan yang diberikan oleh mitra kerja pembangunan (pemerintah daerah, lembaga swasta dan LSM) dalam perencanaan dan pengelolaan program bersifat partisipatif.

5. Meningkatkan kemampuan dan kompetensi mahasiswa sesuai dengan bidang studi yang ditekuni.

6. Membantu kontribusi teoritis dan praktis dalam pengembangan kurikulum yang disesuaikan dengan kebutuhan pembangunan.

Dalam Jurnal Trixie Salawati, Rahayu Astuti, Rizki Nurul Hayati yang mengutip dari buku Mengolah Sampah Untuk Pupuk Pestisida Organic, 2006 karangan Nur Hidayat, Sampah merupakan bahan buangan dari kegiatan manusia atau hasil samping dari aktivitas manusia yang sudah tidak terpakai. Sekarang ini jumlah sampah yang dihasilkan oleh manusia semakin meningkat dan tidak sebanding dengan jumlah penduduk, jenis aktifitas dan tingkat konsumsi penduduk terhadap suatu barang. Semakin besar jumlah penduduk, maka semakin besar pula volume sampah yang dihasilkan.

Dalam Jurnal Siti Rachmah yang mengutip dari buku Pengelolaan Kesehatan Lingkungan, 2015 karangan Mundiatun dan Daryanto mengartikan sampah sebagai material sisa yang tidak diinginkan setelah berakhirnya suatu proses. Sampah didefinisikan oleh manusia menurut derajat keterpakaiannya, dalam proses-proses alam sebenarnya tidak ada konsep sampah yang ada hanya produk-produk yang dihasilkan setelah dan selama proses alam tersebut berlangsung.

Adapun menurut American Public Health Association sebagaimana dikutip oleh Arief Sumantri (2015):Sampah 
diartikan sesuatu yang tidak digunakan, tidak terpakai tidak disenangi atau sesuatu yang dibuang. Yang berasal dari kegiatan manusia dan tidak terjadi dengan sendirinya.

Sampah sendiri terbagi menjadi dua, yaitu :

\section{Organik}

Sampah organik adalah komponen sampah yang terdegradasi (cepat membusuk), terutama yang berasal dari sisa makanan. Sampah yang membusuk (garbage) adalah sampah yang dengan mudah terdekomposisi karena aktivitas mikroorganisme. Dengan demikian pengelolaannya menghendaki kecepatan, baik dalam pengumpulan, pembuangan, maupaun pengangkutannya. Pembusukan sampah ini dapat menghasilkan bau tidak enak seperti ammoniak danasam-asam volatil lainnya. selain itu, dihasilkan pula gas-gas hasil dekomposisi, seperti gas metan dan sejenisnya, yang dapat membahayakan keselamatan bila tidak ditangani secara baik. Penumpukan sampah yang cepat mebusuk perlu dihindari. Sampah kelompok ini kadang dikenal sebagai sampah basah, atau juga dikenal sebagai sampah organik. Kelompok inilah yang berpotensi untuk diproses dengan bantuan mikroorganisme, misalnya dalam pengomposan atau gastifikasi.

2. Anorganik
Sampah anorganik adalah sampah yang tidak membusuk atau refuse pada umumnya terdiri atas bahan-bahan kertas, logam, plastik, gelas, kaca, dan lain-lain. Sampah kering (refuse) sebaiknya didaur ulang, apabila tidak maka diperlukan proses lain untuk memusnakannya, seperti pembakaran. Namun pembakaran refuse ini juga memerlukan penanganan lebih lanjut, dan berpotensi sebagai sumber pencemaran udara yang bermasalah, khususnya bilamengandung plastik PVC. Kelompok sampah ini dikenal pula sebagai sampah kering. (Prof. Enri Damanhuri dan Dr. Tri padmi, 2010)

\section{Teknik Pengolahan Sampah}

1. Konvensional

Teknik ini dipakai warga desa Kramatsampang adalah dengan cara mengumpulkan berbagai jenis sampah perumahan, selokan dan lingkungan desa untuk diangkut dan dibuang di sungai yang dekat dengan desa.

Menurut Ubaidillah yang penulis kutip dari tribunjogja.com, penanganan sampah dengan cara demikian merupakan suatu ironi juga tidak ramah lingkungan karena sungai menjadi tempat pembuangan sementara di desa Kramatsampang. Penulis memaklumi karena di desa belum terdapat Tempat Pembuangan Akhir (TPA) sehingga sungai menjadi alternatif lain bagi mereka yang ingin membuang sampah. 
Kebanyakan mereka berfikir, jika membuang sampah di sungai tidak menimbulkan dampak yang begitu besar. Padahal banyak dampak yang dapat ditimbulkan jika sungai tidak dijaga dengan baik.

\section{Modern}

Penanganan sampah dengan cara modern yaitu pengelolaan sampah dengan pendekatan teknologi yang diharapkan penanganan sampah lebih cepat, efektif dan efisien serta dapat memberikan manfaat lain.

Berikut pendekatan dan teknologi pengelolaan dan pengolahan sampah yang bisa dilaksanakan antara lain:

a. Teknologi Komposting

Pengomposan adalah salah satu cara pengolahan sampah, merupakan proses dekomposisi dan stabilisasi bahan secara biologis dengan produk akhir yang cukup stabil untuk digunakan di lahan pertanian tanpa pengaruh yang merugikan. (Wahyu, 2008). Pembuatan kompos dapat dikatakan juga dengan "Daur Ulang", akan tetapi penggunaannya sudah berubah dari kebutuhan sebelumnya menjadi pupuk untuk tanaman.

Di desa Kramatsampang banyak limbah lingkungan yang memungkinkan untuk di daur ulang seperti limbah peternakan kambing, limbah bawang. Pemanfaatan dari limbah peternakan kambing yaitu kotorannya untuk dijadikan sebagai pupuk organik. Ada beberapa cara yang dapat dilakukan agar kotoran kambing dapat dipergunakan dengan baik. Cara tersebut dapat digolongkan menjadi dua, yaitu pengolahan dengan sistem terbuka dan tertutup. Pada sistem terbuka, biasanya kotoran dibiarkan selama satusatuan waktu tertentu ( \pm 3 bulan) dalam sebuah lubang penampung yang telah tersedia dibawah kandang panggung. Cara ini umumnya lebih murah, karena alokasi dana untuk tenaga kerja cukup rendah dan biasanya tidak diperhitungkan, serta tidak menyita waktu. Kotoran yang tertimbun selama satuan waktu tersebut biasanya dipergunakan langsung sebagai pupuk organik, baik dengan cara ditebarkan secara langsung disekitar tanman atau dengan cara dibenamkan dibawah permukaan tanah pada saat dilakukan pengolahan tanah.

Pengolahan dengan sistem tertutup dilakukan dengan cara membenamkan campuran kotoran (feses, sisa pakan dan urine) kambing dalam sutau lubang dibawah permukaan tanah. Lebih disarankan agar lantai dan dinding lubang tempat penampungan terbuat dari bahan yang dapat mencegah terjadinya rembesan air, baik dari bagian dalam maupun dari luar. Selanjutnya lubang yang telah terisi campuran kotoran tersebut ditutup permukaannya $( \pm 30 \mathrm{~cm})$ dengan tanah galian lubang. Timbuann tersebut 
biasanya dikerjakan dibawah naungan berupa atap sederhana, dan diusahakan agar bebas dari genangan air. Tujuannya adalah mencegah hilangnnya beberapa unsur hara, seperti nitrogen. Hilangnya nitrogen ini dapat terjadi sebagai akibat proses pencucian selama musim hujan atau terjadinya penguapan sebagai akibat proses mikroorganisme baik yang aktif secara anaerob maupun aerob.

Timbunan dibiarkan untuk satu-satuan waktu tertentu ( \pm 3 bulan) sebelum dipergunakan sebagai pupuk organik. Hasil olahan dapat dipergunakan dengan cara mencampur/ membenamkan pupuk kandang pada saat pengolahan tanah sedang dikerjakan(Arif, 2018).

b. Pengelolaan sampah menjadi biogas

Sampah organik dan sayur-sayuran dan khusus ayam seperti layaknya kotoran ternak adalah substrat terbaik untuk menghasilkan biogas (Hammad et al, 1999 di muat dalam Hermawan. B, dkk. 2007). Proses pembetukan biogas melalui pencernaan anaerobik merupakan proses bertahap, dengan tiga tahap utama, yakni hidrolisis, asidogenesis, dan metanogenesis. Tahap pertama adalah hidrolisis, dimana pada tahap ini bahanbahan organik seperti karbohidrat, lipid, dan protein di degradasi oleh mikroorganisme hidrolitik menjadi senyawa terlarut seperti asam karbosilat, asamketo, asamhidrogsi, keton, alkohol, gula sederhana, asam-asam amino, H2 dan $\mathrm{CO} 2$. Pada tahap selanjutnya yaitu tahap asidogenesis senyawa terlarut tersebut diubah menjadi asam-asam lemak rantai pendek, yang umumnya asam asetat dan asam format oleh mikroorganisme asidogenetik. Tahap terakhir adalah metanogenesis, dimana pada tahap ini asam-asam lemak rantai pemdek diubah menjadi $\mathrm{H} 2, \mathrm{CO} 2$, dan asetat. Asetat akan mengalami dekarboksilasi dan reduksi C02 kemudian bersama-sama dengan H2 dan $\mathrm{CO} 2$ menghasilkan produk akhir, yaitu metana $(\mathrm{CH} 4)$ dan karbon dioksida (CO2). Keuntungan pembuatan biogas dari sampah kota yaitu tidak perlu penambahan nutrien, karena jumlah $\mathrm{N}$ dan $P$ pada sampah kota yang dalam penelitian ini berupa sampah sayur sangat besar (Oemar.G.R, dkk, 2007)(David Bahrin, 2011).

Biogas yang dihasilkan dari sampah organik merupakan gas yang mudah terbakar dan didominasi senyawa methana (CH4) dan senyawa CO2. Gas ini dihasilkan dari proses permentasi bahanbahan organik oleh bakteri anaerob yang tahan pada wilayah atau area yang kedap udara. Semua jenis bahan organik yang mengandung senyawa karbohidrat, protein, lemak bisa diproses untuk menghasilkan biogas. Namun, keheterogenan sampah organik dapat mengakibatkan bakteri anaeorobik tidak 
dapat hidup sehingga perlu pengolahan lebih lanjut agar sampah tersebut benarbenar dapat digunakan sebagai bahan baku untuk memproduksi biogas. Sampah dari bahan organik yang homogen, baik padat maupun cair sangat cocok sebagai umpan sistem peralatan produksi biogas secara sederhana. Kandungan metana dalam biogas yang diproduksi oleh reaktor/higester berbeda-beda tergantung jenis feed, komposisi masukan, dan lama waktu fermentasi serta kapasitas reaktor.

Di desa Kramatsampang terdapat jenis sampah yang bisa dimanfaatkan untuk menghasilkan biogas diantaranya sayursayuran seperti daun bawang yang jumlahnya banyak dan sebagaimana sampah-sampah organik lainnya seperti kotoran ternak, umumnya sampah organik tersebut tidak banyak dimanfaatkan, tetapi dibiarkan menumpuk dan membusuk sehingga dapat menganggu pemandangan dan mencemari lingkungan. Salah satu cara penanggulangan sampah organik yang potensial untuk dikembangkan di desa Kramatsampang adalah dengan menerapkan teknologi anerobik untuk menghasilkan biogas.

c. Kelompok Sampah

Menurut Arif Sumantri (2015) dan Muchtar (2012) sumber terbentuknya sampah adalah sebagai berikut :

1) Sampah dari pemukiman penduduk. Pada lingkungan masyarakat biasanya sampah dihasilkan oleh suatu keluarga yang tinggal pada suatu bangunan atau asrama. Jenis sampah yang dihasilkan biasanya cenderung organik seperti sisa makanan, sisa makananan yang bersifat basah, kering, abu platik dan lainnya.

2) Sampah dari tempat umum dan perdagangan adalah tempat yang dimungkinkan banyaknya orang berkumpul dan melakukan kegiatan. Tempat-tempat tersebut mempunyai potensi yang cukup besar dalam memproduksi sampah termasuk tempat perdagangan seperti pertokohan dan pasar. Jenis sampah yang dihasilkan umumnya berupa sisa-sisa makanan, sampah kering, abu plastik, kertas, dan kaleng-kaleng sampah lainnya.

3) Sampah dari sarana pelayanan masyarakat milik pemerintah. Yang dimaksud disini misalnya : tempat hiburan umum, pantai, masjid, rumah sakit, bioskop, perkantoran dan sarana pemerintah lainnya. yang menghasilkan sampah kering dan sampah basah.

4) Sampah dari industri. Dalam pengertian ini termasuk sumber alam, perusahaan kayu, dan lain-lain, kegiatan industri baik yang termasuk distribusi ataupun proes suatu bahan mentah. Sampah yang dihasilkan dari 
tempat ini biasanya sampah basah, samapah kering abu, sisa makanan, dan sisa bahan bangunan.

5) Sampah pertanian, yaitu sampah yang dihasilkan dari tanaman dan binatang daerah pertanian misalnya: sampah dari kebun, kandang, ladang atau sawah yang dihasilkan berupa bahan makanan pupuk maupun bahan pembasmi serangga tanaman.

Di desa Kramatsampang juga terdapat berbagai macam kelompok sampah, diantaranya sampah rumah tangga, warung, pertanian dan lainnya. Sampah rumah tangga diantaranya plastik, kertas, sisa makanan, sayuran, besi, kaleng, kaca, kramik dan sisa kain. Sampah warung diantaranyaadalah botol, plastik bekas jajanan, kaleng dan lainnya. Adapun sampah pertanian yaitu berupa sisa batang, daun, ranting, maupun buah busuk yang tidak diambil manfaat atau hasil utamanya lagi, daun bawang dan kulit bawang.

Mundiatun dan Daryanto (2015) mengartikan pengelolaan sampah adalah pengumpulan, pengangkutan, pendaur-ulangan, atau pembuangan dari material sampah yang dihasilkan dari kegiatan manusia, dan biasanya dikelola untuk mengurangi dampaknya terhadap kesehatan, lingkungan atau keindahan. Pengelolaan sampah bisa melibatkan zat padat, cair, gas atau radioaktif dengan metode dan keahlian khusus untuk masingmasing jenis zat. (rachmah, 2016)

\section{Prioritas Program (Action Plan)}

Dari analisis masalah yang dipaparkan diatas, masyarakat dengan didampingi Aparat desa dan seluruh stakeholder terkait guna melakukan kegiatan kebersihan lingkungan yang diikuti oleh beberapa RT dan RW yang menjadi penggerak dari adanya kegiatan gotong royong tersebut. Adapun kegiatan gotong royong yang sudah terlaksana diantaranya pada hari Sabtu tanggal 28 Juli 2018 yang bertempat di gang masjid RT 01/02 RW 04 dan pada hari minggu tanggal 05 Agustus 2018 yang bertempat di gang jambu RT 01/02 RW 03.Kami kelompok 48 melaksanakan gotong royong bersama masyarakat di dua gang, yaitu di rw 4 dan rw 3. Kami mendapatkan banyak sampah yang menyumbat saluran air di gang tersebut, yang berakibat selokan air tersebut tidak berfungsi dengan baik.

Masyarakat desa Kramatsampang sangat antusias dengan diadakannya Gotong royong, karena sebelumnya tidak ada kegiatan semacam ini. Maka dari itu 
untuk menindak lanjuti kebersihan di Desa Kramatsampang ini, diberikan saran kepada salah satu ormas NU (Ansor) untuk membentuk suatukelompok sampah. Setelah ada saran itu sebagian anggota dari ormas NU (ansor) melakukan musyawaroh untuk membahas mengenai masalah sampah di desa Kramat sampang untuk ke depannya agar di adakan kelompok sampah yang akan di gerakkan oleh anggota ansor.

Adapun dari pihak aparat desa yang diwakili oleh sekretaris desa ketika acara musyawarah desa berlangsung pada malam Sabtu tanggal 10 agustus 2018 menyampaikan hasil musyawarah tiap dusun bahwa mereka menyetujui akan adanya penyediaan bak sampah setiap gang. Akan tetapi usulan yang telah disampaikan oleh sekretaris desa mengenai bak sampah akan berjalan pada tahun 2019 dikarenakan pada tahun 2018 dari pihak kecamatan Kersana sedang menjalankan program perbaikan jalan dan pendidikan.

\section{PENUTUP}

Berdasar pada uraian yang telah dikemukakan di atas, maka penelitian ini dapat disimpulkan sebagai berikut: Strategi dakwah bil hal dalam program Pos Pemberdayaan Keluarga atau PAR dapat berupa forum kumunikasi, advokasi dan wadah kegiatan penguatan fungsi- fungsi keluarga secara terpadu, juga menjadi wadah pelayanan keluarga secara terpadu, yaitu pelayanan pengembangan keluarga secara berkelanjutan, dalam berbagai bidang, utamanya kesehatan, pendidikan dan wirausaha.

Desa KramatSampang merupakan desa yang mempunyai potensi pertanian yang baik, karena terdapat berbagai macam hasil pertanian yang dapat mensejahterakan masyarakat desa KramatSampang. Sebagain besar mata pencaharian masyarakat desa kramatsamapang adalah sebagai buruh tani.

Namun, terdapat beberpa permasalahan di desa kramatsampang yang telah lama belum dapat terselesaikan. Salah satunya yaitu sampah yang berada di desa kramatsampang, karena rendahnya tingkat kesadaran dari masyakat desa kramat sampang untuk menjaga kebersihan linkungan, dan faktor lain dari permasalahan sampah dikarenakan belum adanya tepat pembuangan akhir (TPA) dari sampah tersebut.

\section{DAFTAR PUSTAKA}

Al-Mawardi. (1992) Al-Dakwah; Qawai'dwa Ushul Mesir. Mesir: Dar al-Fikr

Amin, M. (2012). Konsep Dakwah Melalui Program PAR Berbasis Masjid. Tabligh, 13(1), 97-108. 
Hidayat, A. S. (2013). Membangun Dimensi Baru Dakwah Islam: Dari Dakwah Tekstual menuju Dakwah Kontekstual. Jurnal RISALAH, 24(2).

Kurniawan, A. (2017). Bil Hal Penciptaan Budaya Agama melalui Pembiasaan Shalat Berjamaah di Sekolah Menengah Pertama Islam Al-Azhar 5 Kota Cirebon. Orasi: Jurnal Dakwah dan Komunikasi, 8(1), 50-67.

Rekonstruksi Spirit Harmoni melalui Kegiatan PKM PAR Berbasis Masjid di Kecamatan Pulung, Kabupaten Ponorogo. (2015). Mukhibat, 14(2), 55-67.

Tike, Sukmawati, A. W. (2013). Agen Perubahan dan Perannya terhadap Kondisi Sosial Masyarakat di Desa Milatiharjo Kecamatan Gajah Kabupaten Demak. Journal of Educational Social Studies, 2(1), 22-28.

A. Afandi, R. (2013). Integrasi pendidikan lingkungan hidup melalui pembelajaran IPS di sekolah dasar sebagai alternatif menciptakan sekolah hijau. PEDAGOGIA: Jurnal Pendidikan, 2(1), 98-108.

Apritama, M. R., Oktiawan, W., \& Wardhana, I. W. (2016). STUDI PEMILIHAN LOKASI TPA REGIONAL BREGASMALANG (BREBES, TEGAL, SLAWI, PEMALANG). Jurnal Teknik Lingkungan, 5(2), 1-8.

Gerzia, G., Wardhana, I. W., \& Oktiawan, W. (2016). PERENCANAAN DETAIL ENGINEERING DESIGN (DED) TEMPAT PEMROSESAN AKHIR (TPA) BREGASMALANG (BREBES, TEGAL, SLAWI, PEMALANG). Jurnal Teknik Lingkungan, 5(3), 1-5.
Juandi, M. (2012). Analisa pencemaran air tanah berdasarkan metode geolistrik studi kasus tempat pembuangan akhir sampah Muara Fajar Kecamatan Rumbai. Jurnal Ilmu Lingkungan, 3(02).

Mahardini, S. (2012). Pengembalian Fungsi Daerah Sekitar Sungai: Konflik dan Tantangan Dalam Proses Regenerasi Sungai Cikapundung, Bandung. JURNAL PEMBANGUNAN WILAYAH \& KOTA, 8(3), 239-246.

Mahyudin, R. P. (2017). Kajian Permasalahan Pengelolaan Sampah dan Dampak Lingkungan di TPA (Tempat Pemrosesan Akhir). Jukung (Jurnal Teknik Lingkungan), 3(1).

Mulyana, R. (2009). Penanaman etika lingkungan melalui sekolah perduli dan berbudaya lingkungan. Jurnal

Tabularasa, 6(2), 175-180.

Purnomo, D., Indrowati, M., \& Karyanto, P. (2013). Pengaruh Penggunaan Modul Hasil Penelitian Pencemaran di Sungai Pepe Surakarta sebagai Sumber Belajar Biologi Pokok Bahasan Pencemaran Lingkungan terhadap Hasil Belajar Siswa. Pendidikan Biologi, 5(1).

Purwanta, W., \& Susanto, J. P. (2017). Laju Produksi dan Karakterisasi Polutan Organik Lindi dari TPA Kaliwlingi, Kabupaten Brebes. Jurnal Teknologi Lingkungan, 18(2), 157-164.

Sahwan, F. L. (2011). Sistem pengelolaan limbah plastik di Indonesia. Jurnal teknologi lingkungan, 6(1).

Subekti, S. (2010). Pengelolaan Sampah Rumah Tangga 3R Berbasis 
Masyarakat. Prosiding $\quad$ SNST

Fakultas Teknik, 1(1).

Sulistyorini, L. (2005). Pengelolaan sampah dengan cara menjadikannya kompos. Jurnal Kesehatan Lingkungan, 2(1).

Wardani, S. P. R. (2008). Pemanfaatan limbah batubara (Fly Ash) untuk stabilisasi tanah maupun keperluan teknik sipil lainnya dalam mengurangi pencemaran lingkungan. Semarang: UNDIP Press.

Yudhistira, Y., Hidayat, W. K., \& Hadiyarto, A. (2011). Kajian dampak kerusakan lingkungan akibat kegiatan penambangan pasir di Desa Keningar daerah kawasan Gunung Merapi. Jurnal Ilmu Lingkungan, 9(2), 76-84.

(2018). Model Dakwah Berbasis Masjid. Jurnal Al-Khitabah,, 4(1), 17 - 31.

Zakiyyah, Z., \& Haqq, A. A. (2018). Strategi Dakwah Bil Hal Dalam Program Posdaya Berbasis Masjid. ORASI: Jurnal Dakwah dan Komunikasi, 9(1), 127-143. 